\title{
Protective effects of the GLP-1 mimetic exendin-4 in Parkinson's disease
}

Dilan Athauda ${ }^{1} \&$ Thomas Foltynie ${ }^{1}$

${ }^{1}$ Sobell Department of Motor Neuroscience, UCL Institute of Neurology \& The National Hospital for Neurology and Neurosurgery, Queen Square, London, WC1N 3BG

Corresponding author:

Professor Thomas Foltynie, Sobell Department of Motor Neuroscience, UCL Institute of Neurology \& The National Hospital for Neurology and Neurosurgery, Queen Square, London, WC1N 3BG Email address: T.Foltynie@ucl.ac.uk

Telephone: +44 203448 8726, Fax: +44 2034488642

\begin{abstract}
There is increasing interest in the potential role of glucagon-like peptide-1 (GLP-1) receptor agonists as neuroprotective treatments in neurodegenerative diseases including Parkinson's disease following the publication of the results of the Exenatide-PD trial. Of the current GLP-1 receptor agonists already licensed to treat Type 2 diabetes several including exenatide, liraglutide and lixisenatide are the subject of ongoing clinical trials in PD. The underlying rationale for using drugs licensed and effective for T2DM in PD patients therefore needs to be scrutinized, and the results obtained to date critically reviewed. We review the relationship between insulin resistance and Parkinson's disease, the implications on pathogenesis and the efforts to reposition GLP-1 agonists as potential treatments for Parkinson's disease and give an overview of the pre-clinical and clinical data supporting the use of exenatide in Parkinson's disease with a discussion regarding possible mechanisms of action.
\end{abstract}

\section{Keywords}

Parkinson's disease; Exenatide; Glucagon-like peptide-1 agonist; Insulin resistance; Neuroprotection 


\section{Highlights}

- Insulin resistance may be a feature of PD

- GLP-1 agonists have beneficial effects on cellular processes disrupted in PD

- Neuroprotective effects of GLP-1 agonists may be due to restoration of insulin dysfunctional signaling

- Exenatide improved motor severity in a randomized, double-blind trial of PD 
There is increasing interest in the potential role of GLP-1 receptor agonists as neuroprotective treatments in neurodegenerative diseases including Parkinson's disease. Of the current GLP-1 receptor agonists already licensed to treat Type 2 diabetes several including exenatide, liraglutide and lixisenatide are the subject of clinical trials in PD. The underlying rationale for using drugs licensed and effective for T2DM in PD patients therefore needs to be scrutinized, and the results obtained to date critically reviewed.

\section{Parkinson's disease and Type 2 diabetes}

Epidemiological data studying the association between PD and T2DM have revealed inconsistent results (Hu et al., 2007; Palacios et al., 2011; Schernhammer et al., 2011; Sun et al., 2012; Wahlqvist et al., 2012) which may in part be due to the heterogeneity of published studies (case control vs. cohort), the method of defining PD (individual examination vs. self-report), and the method of defining diabetes (self-report, medical records or formal glucose/ insulin measurements). Also it seems that the duration of the diagnosis of T2DM may be relevant (De Pablo-Fernandez et al., 2017; Xu et al., 2011) as may the confounding associated with the choice of treatment given to T2DM patients. Patients who use metformin or thiozolidinediones appear to have a lower risk of PD compared to those on sulphonylureas (Brauer et al., 2015; Wahlqvist et al., 2012); while a recent study suggested patients on dipeptidyl peptidase-IV (DPP-IV) inhibitors (which increase the circulating levels of endogenous GLP-1) also have a lower risk of PD (Svenningsson et al., 2016). Furthermore, the presence of T2DM has been associated with more severe PD symptoms and accelerated disease progression (Cereda et al., 2012; Giuntini et al., 2014).

The pathophysiological changes that lead to the development of PD are broadly accepted to relate to the toxicity associated with oligomeric forms of alpha synuclein, and their interaction with lysosomal function and processes of autophagy, mitochondrial function and mitophagy, as well as neuroinflammation and these pathways have been identified as possible targets for intervention for putative disease modifying therapies (Athauda and Foltynie, 2014). However the importance of metabolic dysfunction in PD is being increasingly recognized (De Pablo-Fernández et al., 2016) and dysfunctional insulin signaling or insulin resistance and its effects on the pathogenesis of PD is 
particularly important. Studies show that neurons are especially vulnerable to stress in the presence of dysfunctional insulin signaling (Choi et al., 2005), while conversely disrupted insulin signaling leads to accumulation of oxidative stress and PD pathology (Morris et al., 2008; Wang et al., 2014), thus linking PD and insulin signaling in a complicated positive feedback system.

\section{Insulin signaling}

Dysregulated insulin signaling due to the development of insulin resistance may underlie shared pathological processes between T2DM and PD and furthermore can influence neurodegeneration. The majority of insulin in the brain is primarily produced peripherally, however it has also synthesized by pyramidal neurons in the cortex, hippocampus and olfactory bulb (Devaskar et al., 1994; Kuwabara et al., 2011), where densities of the insulin receptor are high (Baskin et al., 1988; Havrankova et al., 1978; Hill et al., 1986). In the brain, insulin modulates many biological processes including energy homeostasis and neuronal survival. The effects of insulin are mediated by insulin-receptor substrate-1 (IRS-1) which acts a hub for transmitting the insulin signal through subsequent downstream intracellular pathways. These pathways can be simplified into two main branches and involve the PI3K-Akt pathway and the consequent expression of effectors including mechanistic target of rapamycin (mTOR), glycogen synthase kinase 3 beta (GSK-3b), and forkhead box protein 01 (FOX01) among others which have profound effects on autophagy, apoptosis, mitochondrial function and mediators of neuroinflammation (Greene et al., 2011); and the MAPK/ERK pathway which has a major role in synaptic plasticity.

Of its many functions of relevance in regards to promoting cellular survival with particular relevance to $\mathrm{PD}$, insulin signalling has been shown to be involved in the appropriate degradation of alpha synuclein (Gao et al., 2015; Sandeep K Sharma et al., 2015), enhancing amyloid beta clearance from the brain, preventing extracellular accumulation and eventual fibril and plaque formation (Ashpole et al., 2015; Carro et al., 2002; Watson et al., 2003), and inhibiting hyperphosphorylation of tau, enhancing binding to microtubules, limiting its toxic gain of function (Tokutake et al., 2012). Via its downstream effects on SIRT1 and PCG1a (both master regulators of mitochondrial function), insulin signalling is also involved in regulating mitochondrial biogenesis (Cheng et al., 2010) and limiting 
oxidative stress and modulating inflammatory pathways (Jha et al., 2015). In addition, primarily via activation of the MAPK pathway, insulin has been shown to play a key role in learning and memory and has been shown to regulate hippocampal synaptic and structural plasticity (Chiu et al., 2008; Lee et al., 2005; Yao et al., 2004).

\subsection{Insulin resistance in animal models}

Despite a paucity of experimental models that combine both PD and T2DM pathology in a single model, rodent models of insulin resistance and T2DM have been developed which display not only common metabolic abnormalities including peripheral insulin resistance but also neuronal insulin resistance - allowing them to be utilised to explore the interactions between insulin resistance and PD (Reagan, 2012). Rodents models of insulin resistance demonstrate accelerated dopaminergic cell loss when exposed to MPTP, enhanced microglial activation and deposition of alpha synuclein and display more severe motor, anxiety-like behaviours than controls (Arnold et al., 2014; Choi et al., 2005; Kleinridders et al., 2015; Morris et al., 2011, 2010; Wang et al., 2014). Also rodents fed a high-fat diet to induce neuronal insulin resistance show decreased expression of PSD-95, a scaffolding protein enriched in post-synaptic densities, and synaptopodin, an actin-associated protein enriched in spine apparatuses, resulting in impaired spatial working memory (Arnold et al., 2014). Furthermore, rats depleted of dopamine using the toxin 6-hydroxydopamine (6-OHDA) develop impaired insulin signaling in the basal ganglia (Morris et al., 2008).

In addition the relationship between dopamine depletion and insulin resistance has further been explored. Insulin resistance in rodents is associated with decreased expression of surface dopamine transporter in the striatum (Jones et al., 2017) and rodents demonstrate reduced dopamine turnover (and interestingly also have more nigral iron deposition on MR imaging) (Baladi et al., 2015; Morris et al., 2011); and demonstrate reduced insulin-evoked striatal dopamine release (Stouffer et al., 2015). Similarly, in an novel insulin-resistant transgenic PED/PEA-15 mouse model, there was reduction in striatal tyrosine hydroxylase and dopamine concentrations in association with the development of parkinsonism (Perruolo et al., 2016). 


\subsection{Neuronal insulin resistance}

Measuring and quantifying central insulin resistance is now increasingly possible through our understanding of the methods of normal insulin signaling via the insulin receptor and phosphorylation of IRS-1, which is required to effect its downstream pathways and has numerous phosphorylation sites, including both serine and tyrosine residues. While tyrosine residues are needed for activation of IRS proteins, phosphorylation of IRS-1 at serine residues occurs as part of negative feedback mechanisms and acts to "deactivate" IRS proteins and thus attenuate insulin signaling (Herschkovitz et al., 2007). Serine phosphorylation of IRS-1 can occur through a variety of pathways including mTORC/S6K (Gao et al., 2015; Tremblay et al., 2007), IкB kinase (IKK) (Herschkovitz et al., 2007), c-Jun Nterminal kinase (JNK) ((Lee et al., 2003) and protein kinase C (PKC) (Müssig et al., 2005). Interestingly, a recent study has also identified a new function of tau protein as a negative regulator of insulin signaling, via interaction with PTEN, a phosphatase known to inhibit insulin signaling through the PI3K-Akt pathway (Marciniak et al., 2017), suggesting additional mechanisms.

Insulin resistance is not specific to PD and there are links to other neurodegenerative diseases. Studies in patients with $\mathrm{AD}$ have demonstrated that IRS-1 phosphorylated at serine residue positions 312, 616 or 636 in hippocampal tissues is associated with attenuated insulin signaling and thus have been widely accepted as measures of neuronal insulin resistance (Moloney et al., 2010; Talbot et al., 2012; Yarchoan et al., 2014). Furthermore, these markers of neuronal insulin resistance have been found in other alpha synucleinopathies and tauopathies. Increased expression of IRS-1 Ser312 has been demonstrated in neurons and oligodendrocytes in the putamen of patients with multiple systems atrophy (MSA) (Bassil et al., 2017), and elevated levels of IRS-1 Ser616 seen in hippocampal tissue in patients with corticobasal syndrome and progressive supranuclear palsy (Yarchoan et al., 2014). However, perhaps highlighting the importance of variation between cell models and experimental conditions are conflicting data from mice models that Ser307 phosphorylation (equivalent to human Ser312) actually enhances insulin signaling in vivo (Copps et al., 2010).

Parallel studies have provided indications that dysfunctional phosphorylation of IRS-1 also occurs in PD. It has long since been shown that there is a loss of insulin receptor mRNA in the substantia nigra 
pars compacta in post mortem brains from patients with PD compared with age-matched controls (Moroo 1994). More convincing is a study demonstrating elevated levels of IRS-1 Ser312 found in putaminal neurons in PD patients compared to controls (Bassil et al., 2015) and elevated levels of IRS1 Ser616 has also been found in the hippocampal tissue of PD and PDD patients (Yarchoan et al., 2014).

\subsection{Insulin resistance and alpha synuclein}

The oligomerisation of alpha synuclein and formation of intracellular and extracellular Lewy bodies and Lewy neurites is the key pathological hallmark of PD (Martin et al., 2004) and increasing studies have suggested possible mechanistic links between the development of insulin resistance and alpha synuclein. It is well recognized that overexpression of alpha synuclein is in itself sufficient to cause PD (Ibáñez et al., 2004; Singleton et al., 2003) and modeling this process using alpha synuclein overexpressing transgenic mice showed that alpha-synuclein overexpression led to increased IRS-1 Ser636 in the cortex, striatum and midbrain (and subsequent reduction in insulin-induced Akt pathway signaling) (Gao et al., 2015), suggesting alpha synuclein may act as a negative regulator of insulin resistance. These effects were mediated by alpha synuclein induced hyperactivation of mTORC1/S6K1, and inhibition of protein phosphatase (PP) 2A - causing sustained negative feedback of the insulin signaling pathway. In addition, alpha synuclein has been shown to increase activation of c-Jun N-terminal kinase (JNK) (Rannikko et al., 2015), which leads to increased IRS-1 Ser312 and also acts as a negative regulator of the insulin signaling pathway (Lee et al., 2003). Furthermore, alpha synuclein also induces dephosphorylation (and activation) of GSK-3B (Duka et al., 2009), a kinase involved in promoting alpha synuclein expression (and tau phosphorylation) and found in elevated levels in PD patients and experimental models of PD (Hernandez-Baltazar et al., 2013; Wills et al., 2010). More recently it has been shown that insulin resistance reduces expression of insulin degrading enzyme (IDE) (Sun et al., 2016), a zinc-metalloendopeptidase that can degrade insulin (and amyloid beta) and can inhibit alpha-synuclein fibril formation by binding to alpha-synuclein oligomers, blocking them from forming fibres (Sandeep K Sharma et al., 2015; Sandeep K. Sharma et al., 2015), thus providing a further link between insulin resistance and PD pathology. Thus a damaging feed forward loop, whereby alpha-synuclein exacerbates neuronal insulin resistance, via serine 
phosphorylation of IRS-1, leading to a reduction in downstream insulin signalling and subsequent Akt activation, (and thus reduced inactivation of GSK-3B), which in turn leads to reduced alpha synuclein clearance is possible.

Although it remains to be conclusively shown whether dysregulated insulin signaling is a primary contribution to PD or a secondary consequence of the neurodegenerative process, defective insulin signaling is increasingly recognized in its association with PD and overcoming this with interventions that aim to reverse brain insulin resistance are increasingly being recognized as possible novel therapeutics (D. Athauda and Foltynie, 2016; Aviles-Olmos et al., 2013b; Bassil et al., 2017; Diehl et al., 2017).

\section{Glucagon-like peptide-1}

Glucagon-like peptide-1 (GLP-1) is one of two endogenously secreted incretin hormones known for mediating glucose homeostasis and activates similar pathways to insulin. Secreted by enteroendocrine cells of the small intestine in response to food, GLP-1 stimulates insulin secretion from the pancreas and reduces hepatic gluconeogenesis (Baggio and Drucker, 2007). In vitro, GLP-1 also exerts trophic effects, enhancing islet beta cell proliferation and differentiation, inhibiting apoptosis, and enhancing cell survival (Drucker et al., 2010; Lovshin and Drucker, 2009). These effects are primarily mediated by activation of PI3K/Akt and AMPK/mTOR pathways (Alismail and Jin, 2014; Wang et al., 2004) and down regulation of various apoptotic pathways including caspase-9 and -3 (Li et al., 2013; Tews et al., 2009). GLP-1's actions are mediated via the GLP-1 receptor (GLP-1R), a 7-transmembrane spanning G-protein coupled receptor. Following activation of the alpha subunit of the GLP-1R, adenyl cyclase is activated leading to an increase of intracellular cAMP, which then activates protein kinase A (PKA), and phosphoinositide 3-kinase (PI3K), which phosphorylates and activates a variety of downstream signalling pathways. The GLP-1R widely expressed in pancreatic islet cells (as well as other peripheral tissues such as the lungs, heart and kidneys) but also selectively expressed in neurons throughout the brain, with high densities in the frontal cortex, hypothalamus, thalamus, hippocampus, cerebellum and substantia nigra (Alvarez et al., 2005; Trapp et al., 2015) and also found in astrocytes and glial cells (Kappe et al., 2012; Reiner et al., 2016; Spielman et al., 2017). The majority of GLP-1 
in the CNS is produced peripherally and can freely cross the blood-brain-barrier by diffusion, but is also produced locally by neuronal and glial cells (Heppner et al., 2015; Kappe et al., 2012). In the brain, in addition to its effects on autonomic and neuroendocrine function (reviewed (Seufert and Gallwitz, 2014)), GLP-1 is involved in promoting neuronal growth and proliferation, reducing oxidative stress, inhibiting apoptosis and modulating inflammatory pathways (Bassil et al., 2014; Hamilton et al., 2011; Spielman et al., 2017; Teramoto et al., 2011). However, due to its rapid cleavage and degradation by circulating enzyme DPP-IV, a variety of synthetic GLP-1 agonists have been formulated to overcome its short duration of action and are now used in the treatment of T2DM (Madsbad, 2016), and are also being explored in regards to effects on weight loss and cardiovascular function (Manigault and Thurston, 2016; Mora and Johnson, 2017).

\section{Exenatide}

Exenatide was the first synthetic GLP-1 agonist to be developed and licensed for use in T2DM, based on a peptide (exendin-4) - discovered in the saliva of the Gila monster (Heloderma suspectum) that shares 53\% homology to human GLP-1 and importantly, is naturally resistant to the action of DPP-IV (Parkes et al., 2013). Peripherally administered exenatide can cross the blood brain barrier in rodents (Hunter and Hölscher, 2012) and humans (Athauda et al., 2017a) and can influence a number of cellular processes. Over the years numerous in vitro and in vivo studies have evaluated the neuroprotective and neurotrophic effects of exenatide in a variety of models of neurodegenerative diseases (Dilan Athauda and Foltynie, 2016).

\subsection{Exenatide and neuroprotection}

The continued integrity of mitochondria within cells is critical to its sustained health and mitochondrial dysfunction causing imbalance between processes that generate reactive oxygen species (ROS) and those that eliminate ROS have been identified as playing a key role in the selective vulnerability of dopaminergic neurons in the pathogenesis of PD (Schapira, 2008). Exendin-4 has been shown to protect rodent insulinoma cells from human islet amyloid polypeptide (hIAPP)-induced apoptosis via improved mitochondrial function and Akt-induced inactivation of FOX01 (Fan et al., 2010), while in rodents treated with mitochondrial toxins, GLP-1 stimulation was shown to preserve mitochondrial 
function in dopaminergic neurons by increasing expression of complex I and anti-apoptotic proteins Bcl-2, while reducing caspase-3 activation, leading to attenuation of cell death (Chen et al., 2015; Nassar et al., 2015).

Additional sources of oxidative damage and inflammation in PD can occur from inappropriate and sustained activation of peripheral macrophages and glial cells due to a variety of stressors including alpha synuclein, inflammatory cytokines and neighboring cell death (Béraud et al., 2013; Blandini, 2013; Gallegos et al., 2015). Cell death associated with oxidative stress can be modelled by a variety of stressors in vitro. Exenatide and GLP-1 stimulation has been shown to protect SH-SY5Y and primary ventral mesencephalic cells from hydrogen peroxide- and 6-OHDA-induced cell death (Li et al., 2010, 2009).

Dysfunction of lyososomal systems and disruption of normal processes through which cells degrade abnormal proteins/cellular constituents (autophagy) and the aggregation of alpha-synuclein into toxic fibrils, are thought to be critical steps in the process leading to degeneration of dopaminergic neurons in PD. The co-existence of amyloid beta and tau pathology in PD is well known and interactions can often lead to a deleterious feed-forward loop responsible for the development and spreading of neurodegeneration (Irwin et al., 2013; Moussaud et al., 2014). In various rodent models, GLP-1 stimulation has demonstrated beneficial effects of monomeric alpha synuclein load in the striatum (Bassil et al., 2017), reduce soluble amyloid beta levels and plaque load, and reduce tau hyperphosphorylation (Xu et al., 2015)(Chen et al., 2012).

In view of the influence GLP-1R stimulation has on diverse cellular processes involved in PD pathogenesis, exenatide has also been used in a variety of animal toxin models of PD. These widely used models rely on the use of locally or systemically administered neurotoxins (commonly 6-OHDA, MPTP or LPS) to induce dopaminergic cell loss and the development of a parkinsonian-like phenotype. Administration of MPTP to rodents resulted in dopaminergic cell loss in the substantia nigra (as measured by a reduction in TH-immunoreactive cells), dopamine and dopamine metabolites and subsequent motor function deficits as assessed by performance on the pole test, beam traverse, 
open-field activity, and rotarod (Li et al., 2009), while a separate study showed MPTP-treated rodents had increases in Mac1 and MMP-3 (markers of microglia activation) and elevated levels of proinflammatory cytokines TNF- $\alpha$ and IL-1 $\beta$ (Kim et al., 2009) in association with dopaminergic cell loss. Both studies showed that pre-treatment with exenatide provided complete protection against dopaminergic cell loss, suppressed MPTP-induced activation of microglia and attenuated expression of pro-inflammatory molecules leading to improved performed on motor assessments that were essentially no different to controls. Similarly, rats unilaterally administered 6-OHDA or LPS into the median forebrain bundle led to significant reductions in striatal $\mathrm{TH}+$ activity and dopamine concentration (Harkavyi et al., 2008), with the animals exhibiting marked apomorphine and amphetamine-induced rotational behavior (indicative of the severity of nigrostriatal lesion) (Bertilsson et al., 2008). In these studies, exenatide was administered well after the nigrostriatal lesion had been allowed to establish and still resulted in normalization of apomorphine- and amphetamine-induced circling in a dose dependent manner. Furthermore, immunostaining of the striatum demonstrated exendin-4 significantly increased the number of both tyrosine hydroxylase- and vesicular monoamine transporter 2-positive neurons in the substantia nigra above the control values, suggesting exenatide may be able to halt and reverse established nigrostrial lesions, with obvious encouraging implications for treating established PD.

Taken together, GLP-1 stimulation has a remarkable array of protective effects on cellular proliferation, differentiation, inflammatory pathways, mitochondrial function and dopaminergic survival that is associated with restoration and reversal of motor deficits in animal toxin models of PD that may have therapeutic benefits in patients.

\section{Unravelling the mechanism of action}

The distribution of tissues that are receptive to GLP-1 suggest a multi-modal mechanism of action to explain the potential therapeutic effects of GLP-1 stimulation (Figure 1). Activation of the GLP-1R leads to an increase of intracellular cAMP, which then activates protein kinase A (PKA), and phosphoinositide 3-kinase (PI3K) which and activates a variety of downstream signalling pathways including protein Akt, and this pathway has been identified of being of potential relevance to the 
actions of GLP-1. As a master regulator of cellular function, Akt can influence important downstream effectors such as GSK-3B, mTOR, caspase-9 and FOXO1 (which have themselves been identified as novel targets for halting neurodegeneration in PD) and ultimately promote a cell survival pathway (Greene et al., 2011). Alterations in Akt signalling may be a key component of PD pathogenesis and influence alpha-synuclein aggregation (Kim et al., 2011) and in vivo studies which utilise selective Akt inhibitors suggest the Akt activation is at least partially responsible for the effects of GLP-1R stimulation on cellular proliferation (Wang et al., 2004), trophic effects (Zhou et al., 2015) and antiapoptotic effects (Wang et al., 2012; H. Zhang et al., 2015). Akt activation inactivates GSK-3B, a major kinase typically involved in promotion of alpha synuclein induced neurodegeneration (and also tau phosphorylation and amyloid beta aggregation), and seen hyperactivated in animal models of PD (Hernandez-Baltazar et al., 2013), and found in elevated levels co-localised with alpha nuclein in postmortem striata of patients with PD (Nagao and Hayashi, 2009; Wills et al., 2010). Thus the beneficial effects of GLP-1 stimulation on protein aggregation may be partially mediated through PI3K/Aktinduced inactivation of GSK-3B (Chen et al., 2014; Ma et al., 2015; Yang et al., 2013). In addition, a recent study showed that geniposide, a novel GLP-1 agonist, can up-regulate expression of IDE (known to inhibit amyloid beta and alpha synuclein fibril formation), effects which were attenuated in the presence of PI3K inhibitors (Y. Zhang et al., 2015).

In parallel, some of the neurotrophic effects seen following GLP-1 stimulation such as upregulation of BDNF are mediated by activation of the Akt pathway and increases in intracellular cAMP - BDNF is itself a transcriptional target of cAMP response element-binding protein (CREB). Similarly, GLP-1Rinduced activation of Akt leading to inhibition of FOX01 and reduced production of pro-apoptotic proteins (BiM, FAS) while concurrent GLP-1R-induced elevation of cAMP enhances upregulation of anti-apoptotic proteins (Bcl-2, Bcl-XL). Together, these actions contribute to preserve mitochondrial function by helping stabilise the outer mitochondrial membrane, preventing efflux of cytochrome c into the cytoplasm, reducing activation of caspase- 9 and -3 , subsequently resulting in reduced apoptosis and oxidative stress (Li et al., 2013; Tews et al., 2009; Zhan et al., 2012). With regards to effects on neuroinflammation, one proposed mechanism involves Akt-induced down regulation of tolllike receptor-4 (which plays a critical roles in the recognition of oligomeric alpha-synuclein and 
subsequent microglial activation) (Park et al., 2014) and modulation of transcription factor nuclearfactor $\kappa \mathrm{B}(\mathrm{NF}-\kappa \mathrm{B})$, an important downstream target of the GLP-1R/PI3K/Akt pathway which regulates inflammatory gene expression and mediates the pro-inflammatory response of microglial cells (Khasnavis et al., 2012).

In regards to further actions of GLP-1 stimulation on inflammation, it was recently demonstrated that microglia not only express GLP-1R but are also able to secrete and alter expression of GLP-1 depending on inflammatory stimuli (Kappe et al., 2012). As the resident immune cells of the CNS, microglia constantly survey the microenvironment and can shift phenotype from a "quiescent" state to an "activated" state, leading to the secretion of a range inflammatory mediators, growth factors and cytokines that can either initiate/exacerbate oxidative stress and trigger cell death pathways or exert neurotropic properties and anti-inflammatory mediators and aid brain repair pathways (Cherry et al., 2014). A recent study showed that exenatide was able to induce macrophages to the alternative activated M2 "protective" phenotype through activation of the transcription 3 (STAT3) which was associated with increased production of IL-10 (Shiraishi et al., 2012). Therefore, as well as GLP-1 stimulation directly influencing the phenotypic shift to microglial "anti-inflammatory" states (Spielman et al., 2017), exogenous GLP-1 may be able to amplify endogenous secretion of GLP-1, thus providing another link between GLP-1 stimulation and inflammation (Bao et al., 2015; Li et al., 2010).

Insulin signalling has been shown to be important to neuronal survival and as GLP-1R stimulation activates similar pathways "de-activated" as a consequence of insulin resistance, the ability to restore brain insulin sensitivity may be responsible for the diverse range of its pleotrophic effects Recently, in PLP-SYN mice (a model of MSA) exendin-4 treatment decreased expression of IRS-1 Ser307 (human Ser312) and IRS-1 Ser612 in the striatum and this was accompanied by lower levels of monomeric oligomeric alpha synuclein in oligodendrocytes and preservation of dopaminergic neurons in the substantia pars compacta (Bassil et al., 2017).

Similarly, GLP-1 stimulation via activation of the MAPK pathway may underlie its effects on hippocampal synaptic plasticity and structural plasticity (Mainardi et al.). Neurite outgrowth essential for formation of synapses - induced by GLP-1 stimulation, was partially inhibited by MAPK 
inhibitors (Perry et al., 2002), while activation of the PI3K/MAPK/ERK pathway also mediates glutamate and g-aminobutyric acid receptors, enhances protein synthesis and maintains dendritic spine stabilisation, shown to be essential for hippocampal long term potentiation (LTP) and memory consolidation (Goldin M, 2003; Zhao and Townsend, 2009).

As described above pre-clinical data suggests exenatide can normalise dopaminergic function in rodents with nigrostriatal lesions induced by neurotoxins, through apparent improvements in dopaminergic function or restoration / improved survival of dopaminergic neurons; however some studies also suggest exenatide may affect striatal dopamine metabolism, which may underlie some of its clinical effects. In a 6-OHDA rodent model of PD, in which rats were given levodopa after administration of 6-OHDA, exendin-4 dose-dependently increased the amount of extracellular dopamine in response to a given dose of levodopa, with a progressive reduction in levodopa-induced dyskinesia (Abuirmeileh et al., 2012). Similarly, a recent study demonstrated that exendin-4 prevented LPS-induced behavioural decline in rats (as assessed by the forced swim test) and that these changes occurred independently of central or peripheral inflammatory changes, but were associated with alterations in dopamine metabolism (Ventorp et al., 2017). GLP-1 stimulation is known to increase intracellular cAMP (Drucker et al., 1987), while increased cAMP expression upregulates the expression and activity of tyrosine hydroxylase (Kim et al., 1993), the rate limiting enzyme in the synthesis of dopamine. Also, exendin-4 was shown to inhibit the ability of cocaine to increase extracellular dopamine in rats, by increasing expression of surface dopamine transporter (Reddy et al., 2016), thus offering further possible mechanisms for its underlying effects.

\section{Clinical data - open label trial}

Based on the encouraging data from preclinical models of $\mathrm{PD}$, as well as the reassuring safety data from patients treated with exenatide for their Type 2 diabetes (Prasad-Reddy and Isaacs, 2015), it was decided to perform a trial of exenatide in patients with PD (Aviles-Olmos et al., 2013a). These plans were initially discussed between TF and the Cure Parkinson's trust and subsequently with Amylin Pharmaceuticals and the Michael J Fox Foundation. While there was an initial desire to proceed immediately to a double blind, placebo controlled trial, the commercial partner felt that the preclinical 
data required further replication before it would be prepared to provide drug or placebo to enable a double blind trial to proceed. In this context, the Cure Parkinson's trust agreed to provide sufficient funding for TF to perform an Investigator initiated open label trial of exenatide (as Byetta 10mcg subcutaneous injection twice daily) to gain preliminary proof of concept data regarding whether any of the laboratory data could be replicated in patients with PD.

44 patients were recruited into this trial. They were deliberately chosen according to criteria that they would all already be treated with dopaminergic therapies. This was to provide reassurance regarding the certainty of the diagnosis, and minimize the risk of dropout due to the need for the introduction of L-dopa during the period of trial follow up. This also enabled rapid recruitment of patients from a single centre thus keeping the costs of performing the trial to a very modest level. To try and most accurately gauge the motor severity of PD despite dopaminergic replacement, it was decided that patients should be periodically assessed after an overnight period without dopaminergic treatment. Furthermore, to try and distinguish between unanticipated symptomatic effects and possible disease modifying effects, a washout design was chosen such that patients randomized to have supplementary treatment with exenatide continued the drug for 12 months, but then had a further evaluation of the severity of their PD at 14 months, then again at 24 months.

Given the absence of placebo injections, the trial was inevitably susceptible to placebo effects in addition to observer bias. To minimize the impact of the latter bias, all patient assessments were video recorded and scores of the MDS UPDRS part 3 were rated by individuals blinded to treatment allocation.

Patients were approximately 60 years old, had a mean duration of PD of about 10 years and were using a mean of $975 \mathrm{mg}$ of L-dopa equivalents. The group randomized to Byetta, had a 1.7 point improvement at the 14 month point, while the group maintained on conventional medication alone, had deteriorated by 2.8 points by this same point. Of additional interest, among the secondary outcomes, patients on Byetta had improved by 2.8 points on the Mattis dementia rating scale at the 14 month timepoint, while the control group had deteriorated by 3.5 points (Aviles-Olmos et al., 2013a). After extended follow up in the absence of any further treatment with exenatide, assessments were repeated at the 24 month timepoint (Aviles-Olmos et al., 2014). What was striking was that the 
exenatide treated patients were still 1.1 better than their baseline scores on the MDS UPDRS part 3, whereas control patients had declined further and were now 4.6 points worse off than their baseline scores. Given that the scores again had to be rated on video by blinded observers to minimize the risk of observer bias, none of these scores could include any effect on rigidity. Despite this limitation, the consistent marked differences between the 2 groups even a year after stopping the exenatide injections made it harder to believe that these effects could be entirely explained by a placebo effect.

\subsection{Clinical data - double blind trial}

The positive data from the open label trial provided sufficient reassurance for charitable funders to make a larger investment to support a double blind placebo controlled trial of exenatide in PD (Athauda et al., 2017a). This also required the support of the commercial sector to provide GMP drug and GMP matched placebo injections to enable the trial to be conducted in accordance with trial regulations. This was initially agreed with Bristol Myers Squibb and subsequently agreed with Astra Zeneca when the Exenatide product (Bydureon) was transferred between these commercial entities during the setup of the trial. The quantities of drug and placebo agreed was sufficient for 60 patients (30 active drug and 30 placebo) for 1 year and this dictated the size of the trial.

In view of the previous successful use of the MDS-UPDRS part 3 in the practically defined off medication state, the decision was taken to use this measure again as a window into disease severity in patients already treated with dopaminergic replacement. This also had the advantage of keeping the inclusion and exclusion criteria sufficiently broad such that large numbers of prevalent PD patients would be eligible for the trial and could thus be recruited and assessed through a single large PD centre in London, UK. A washout design was again chosen to help distinguish between treatment differences emerging as a result of a symptomatic effect of exenatide and any differences due to a disease modifying effect. Patients were therefore allocated to self-inject either active drug or placebo on a weekly basis for 48 weeks followed by a 12 week washout period.

In addition to a standard range of clinical assessments, patients had serial collection of blood and urine samples as well as 2 lumbar punctures to measure exenatide levels in the CSF. DaTscan imaging was performed at baseline and at the end of the study after exenatide washout. Relevant permissions were 
obtained and recruitment for the trial was completed between June 2014 and March 2015. Sixty weeks later the final data were collected and analyses of the clinical and imaging data were performed.

The trial met its primary outcome of demonstrating a significant difference between groups according to treatment allocation in the MDS UPDRS part 3 in the practically defined off medication state at the 60 week timepoint. The analysis was pre-planned to adjust for any differences between the 2 groups at baseline that occurred by chance despite randomization. The exenatide treated group had an advantage of 3.5 points $(95 \% \mathrm{CI}-6.7$ to $-0.3, \mathrm{p}=0.0318)$ compared to the placebo group. There were no other statistically significant differences between the 2 groups on other outcome measures although the direction of effect favoured exenatide for almost all measures including DaTscan imaging.

\section{Next steps}

The results of the 2 small trials provide hugely encouraging data that exenatide and/or other related drugs may eventually play a role in the treatment of Parkinson's disease (Athauda et al., 2017b; Foltynie and Aviles-Olmos, 2014). There are 2 complementary priorities in taking this science forward through further clinical trials;

1). Clarifying the long term safety and efficacy of exenatide on motor, non motor function and quality of life. The published trial data have shown an encouraging signal of effect in a small population of patients from a single centre treated for 1 year only. As such it is vital that these data are replicated in a larger population of patients using a multi-centre design and with exposure over a longer period. This will also enable outcome measures to be compared that are of greater relevance to patients than the "Practically defined Off medication assessment". These could include "On medication scores from each section of the MDS UPDRS as well as Non Motor symptoms, detailed cognitive assessments and quality of life measures. In addition, although exenatide was well tolerated in patient group, common adverse effects of exenatide and GLP-1 agonists include gastrointestinal related effects such as nausea, vomiting, loss of appetite and weight loss(Mann and Raskin, 2014), which need to be considered when evaluating the use of this class of drugs in patients with PD as it may interfere with the efficacy of orally administered dopaminergic therapy. 
2). Understanding the mechanism of action of GLP-1 agonists in relationship to PD. This is of major scientific importance and will discriminate whether the effects we have seen to date are related to novel symptomatic effects or are disease modifying. This distinction will also greatly inform on how best to deliver this class of agent in the future and how better agents might be developed with greater efficacy and/or improved side effect profiles. The optimal trial design to try and confirm whether a novel agent has a neuroprotective effect in PD depends greatly on whether the same agent might also have symptomatic benefits. This was the case in the evaluation of Rasagiline in the TEMPO and ADAGIO trials and therefore the decision was made to adopt a delayed start design in which patients are randomized to either active drug or placebo during period 1, but then all patients have active drug at the end of period 2. This design means that by the time of the final outcome comparison at the end of period 2, any difference between the 2 groups would not relate to a symptomatic effect but must be the result of a disease modifying advantage resulting from earlier initiation of the treatment. Delayed start designs have however been criticized because of the potential for bias caused by differential dropout during period 1 , and also the inevitable loss of blinding during period 2 which can lead to assessment bias.

An alternative approach that has yet to be used in patients with Parkinson's disease is the randomized withdrawal design. Patients are initially randomized to placebo or active treatment for period 1, however a proportion of those on active treatment will switch to placebo for period 2. Therefore any difference between the 2 groups on placebo at the end of period 2 would be an estimate of the disease modifying effect, while any difference between those still on active treatment and those that switched to placebo would be an estimate of the symptomatic effect of the drug.

Furthermore, in addition to exenatide (the first of the GLP-1 agonists to be developed) a number of newer GLP-1 agonists (based either on the structure of exendin-4 (lixisenatide) or human GLP-1 (liraglutide)) have also demonstrated similar neuroprotective properties across a range of pre-clinical models of PD and other neurodegenerative diseases (Li et al., 2016). In view of differences regarding their pharmacodynamic and pharmacokinetic properties and efficacy in glycaemic control in diabetes (Bergenstal et al., 2010; Buse et al., 2009), it is reasonable to assume similar difference may exist in 
their respective potential efficacy in PD. Comparative studies in models of PD are sparse (Liu et al., 2015) but due to differences in experimental methodology and dosing, firm conclusions as to translational efficacy in humans are difficult to interpret. Similarly, comparable data regarding their ability to penetrate the blood-brain-barrier in humans have obvious implications for potential therapeutic benefits, but again data is scarce. Although exenatide, liraglutide and lixisenatide have all been shown to cross the blood-brain-barrier in rodents (Hunter and Hölscher, 2012; Kastin and Akerstrom, 2003), there are apparent marked differences in the ratio of CSF:serum concentrations in humans; exenatide $2.7 \%$ (Athauda et al., 2017a) versus liraglutide $0.02 \%$ (Christensen et al., 2015) which may have implications for potential therapeutic application. Nevertheless, this class of drugs should be further explored for their potential in treating PD.

\section{Declaration of interest}

The author's own work on Exenatide is supported by the Michael J Fox Foundation for Parkinson's research and the Cure Parkinson's Trust. DA is a co-investigator on the Exenatide-PD trial and has no conflicts of interest. TF has received honoraria for speaking from Profile Pharma, BIAL, Abbvie, Medtronic, and is lead investigator on the Exenatide-PD trial. He has received grant funding from European Union FP7, John Black Charitable Foundation and Rosetrees Trust. 
Figure 1:

Overview of main pathways involved in GLP-1R activation in neurons (left) and consequences of dysfunctional insulin signalling (right). The phosphorylation of IRS protein at tyrosine or serine residues ultimately activates, or inhibits, respectively insulin signalling. PI3K enables phosphorylation of PIP2 to PIP3, which then activates PDK1, which then activate Akt. Tau binding to a fraction of PTEN is necessary to induce formation of PIP3 over PIP2. In models of insulin resistance, accumulation of alpha-synuclein may ultimately exacerbate activation of the mTORC1 pathway and induce microglia activation, raising levels of TNF-alpha, leading to activation of stress kinases such as JNK, both of which lead to IRS phosphorylation at serine residues, exacerbating insulin resistance. Loss of the insulin signalling pathway reduces activation of the AKT pathway, promoting mitochondrial dysfunction, inflammation, oxidative stress and accumulation of alpha-synuclein. * Denotes actions typically seen in microglia.

\section{References}

Abuirmeileh, A., Harkavyi, A., Rampersaud, N., Lever, R., Tadross, J.A., Bloom, S.R., Whitton, P.S., 2012. Exendin-4 treatment enhances L-DOPA evoked release of striatal dopamine and decreases dyskinetic movements in the 6-hydoxydopamine lesioned rat. J. Pharm. Pharmacol. 64, 637-643. doi:10.1111/j.2042-7158.2011.01394.x

Alismail, H., Jin, S., 2014. Microenvironmental stimuli for proliferation of functional islet $\beta$-cells. Cell Biosci. 4, 12. doi:10.1186/2045-3701-4-12

Alvarez, E., Martínez, M.D., Roncero, I., Chowen, J.A., García-Cuartero, B., Gispert, J.D., Sanz, C., 
Vázquez, P., Maldonado, A., de Cáceres, J., Desco, M., Pozo, M.A., Blázquez, E., 2005. The expression of GLP-1 receptor mRNA and protein allows the effect of GLP-1 on glucose metabolism in the human hypothalamus and brainstem. J. Neurochem. 92, 798-806. doi:10.1111/j.1471-4159.2004.02914.x

Arnold, S.E., Lucki, I., Brookshire, B.R., Carlson, G.C., Browne, C.A., Kazi, H., Bang, S., Choi, B.-R., Chen, Y., McMullen, M.F., Kim, S.F., 2014. High fat diet produces brain insulin resistance, synaptodendritic abnormalities and altered behavior in mice. Neurobiol. Dis. 67, 79-87. doi:10.1016/j.nbd.2014.03.011

Ashpole, N.M., Sanders, J.E., Hodges, E.L., Yan, H., Sonntag, W.E., 2015. Growth hormone, insulinlike growth factor-1 and the aging brain. Exp. Gerontol. 68, 76-81. doi:10.1016/j.exger.2014.10.002

Athauda, D., Foltynie, T., 2016. Insulin resistance and Parkinson's disease: a new target for disease modification? Prog. Neurobiol. doi:10.1016/j.pneurobio.2016.10.001

Athauda, D., Foltynie, T., 2016. The glucagon-like peptide 1 (GLP) receptor as a therapeutic target in Parkinson's disease: mechanisms of action. Drug Discov. Today 21, 802-18. doi:10.1016/j.drudis.2016.01.013

Athauda, D., Foltynie, T., 2014. The ongoing pursuit of neuroprotective therapies in Parkinson disease. Nat. Rev. Neurol. 11, 25-40. doi:10.1038/nrneurol.2014.226

Athauda, D., Maclagan, K., Skene, S.S., Bajwa-Joseph, M., Letchford, D., Chowdhury, K., Hibbert, S., Budnik, N., Zampedri, L., Dickson, J., Li, Y., Aviles-Olmos, I., Warner, T.T., Limousin, P., Lees, A.J., Greig, N.H., Tebbs, S., Foltynie, T., 2017a. Exenatide once weekly versus placebo in Parkinson's disease: a randomised, double-blind, placebo-controlled trial. Lancet. doi:10.1016/S0140-6736(17)31585-4

Athauda, D., Wyse, R., Brundin, P., Foltynie, T., 2017b. Is Exenatide a Treatment for Parkinson's Disease? J. Parkinsons. Dis. 7, 451-458. doi:10.3233/JPD-171192

Aviles-Olmos, I., Dickson, J., Kefalopoulou, Z., Djamshidian, A., Ell, P., Soderlund, T., Whitton, P., Wyse, R., Isaacs, T., Lees, A., Limousin, P., Foltynie, T., 2013a. Exenatide and the treatment of patients with Parkinson 's disease 123. doi:10.1172/JCI68295.2730 
Aviles-Olmos, I., Dickson, J., Kefalopoulou, Z., Djamshidian, A., Kahan, J., Fmedsci, P.E., Whitton, P., Wyse, R., Isaacs, T., Lees, A., Limousin, P., Foltynie, T., 2014. Motor and Cognitive Advantages Persist 12 Months After Exenatide Exposure in Parkinson's Disease. J. Parkinsons. Dis. doi:10.3233/JPD-140364

Aviles-Olmos, I., Limousin, P., Lees, A., Foltynie, T., 2013b. Parkinson's disease, insulin resistance and novel agents of neuroprotection. Brain 136, 374-84. doi:10.1093/brain/aws009

Baggio, L.L., Drucker, D.J., 2007. Biology of incretins: GLP-1 and GIP. Gastroenterology 132, 2131-57. doi:10.1053/j.gastro.2007.03.054

Baladi, M.G., Horton, R.E., Owens, W.A., Daws, L.C., France, C.P., 2015. Eating high fat chow decreases dopamine clearance in adolescent and adult male rats but selectively enhances the locomotor stimulating effects of cocaine in adolescents. Int. J. Neuropsychopharmacol. 18, pyv024. doi:10.1093/ijnp/pyv024

Bao, Y., Jiang, L., Chen, H., Zou, J., Liu, Z., Shi, Y., 2015. The Neuroprotective Effect of Liraglutide is Mediated by Glucagon-Like Peptide 1 Receptor-Mediated Activation of cAMP/PKA/CREB Pathway. Cell. Physiol. Biochem. 36, 2366-2378. doi:10.1159/000430199

Baskin, D.G., Wilcox, B.J., Figlewicz, D.P., Dorsa, D.M., 1988. Insulin and insulin-like growth factors in the CNS. Trends Neurosci. 11, 107-11.

Bassil, F., Canron, M.-H., Vital, A., Bezard, E., Li, Y., Greig, N.H., Gulyani, S., Kapogiannis, D., Fernagut, P.-O., Meissner, W.G., 2017. Insulin resistance and exendin-4 treatment for multiple system atrophy. Brain 140, 1420-1436. doi:10.1093/brain/awx044

Bassil, F., Fernagut, P.-O., Bezard, E., Meissner, W.G.T. for disease modifi, 2014. Insulin, IGF-1 and GLP-1 signaling in neurodegenerative disocation? Prog. Neurobiol. doi:10.1016/j.pneurobio.2014.02.005

Béraud, D., Hathaway, H.A., Trecki, J., Chasovskikh, S., Johnson, D.A., Johnson, J.A., Federoff, H.J., Shimoji, M., Mhyre, T.R., Maguire-Zeiss, K.A., 2013. Microglial activation and antioxidant responses induced by the Parkinson's disease protein $\alpha$-synuclein. J. Neuroimmune Pharmacol. 8, 94-117. doi:10.1007/s11481-012-9401-0

Bergenstal, R.M., Wysham, C., Macconell, L., Malloy, J., Walsh, B., Yan, P., Wilhelm, K., Malone, J., 
Porter, L.E., 2010. Efficacy and safety of exenatide once weekly versus sitagliptin or pioglitazone as an adjunct to metformin for treatment of type 2 diabetes (DURATION-2): a randomised trial. Lancet 376, 431-9. doi:10.1016/S0140-6736(10)60590-9

Bertilsson, G., Patrone, C., Zachrisson, O., Andersson, A., Dannaeus, K., Heidrich, J., Kortesmaa, J., Mercer, A., Nielsen, E., Rönnholm, H., Wikström, L., 2008. Peptide hormone exendin-4 stimulates subventricular zone neurogenesis in the adult rodent brain and induces recovery in an animal model of Parkinson's disease. J. Neurosci. Res. 86, 326-38. doi:10.1002/jnr.21483

Blandini, F., 2013. Neural and immune mechanisms in the pathogenesis of Parkinson's disease. J. Neuroimmune Pharmacol. 8, 189-201. doi:10.1007/s11481-013-9435-y

Brauer, R., Bhaskaran, K., Chaturvedi, N., Dexter, D.T., Smeeth, L., Douglas, I., 2015. Glitazone Treatment and Incidence of Parkinson's Disease among People with Diabetes: A Retrospective Cohort Study. PLoS Med. 12, e1001854. doi:10.1371/journal.pmed.1001854 Buse, J.B., Rosenstock, J., Sesti, G., Schmidt, W.E., Montanya, E., Brett, J.H., Zychma, M., Blonde, L., LEAD-6 Study Group, 2009. Liraglutide once a day versus exenatide twice a day for type 2 diabetes: a 26-week randomised, parallel-group, multinational, open-label trial (LEAD-6). Lancet (London, England) 374, 39-47. doi:10.1016/S0140-6736(09)60659-0

Carro, E., Trejo, J.L., Gomez-Isla, T., LeRoith, D., Torres-Aleman, I., 2002. Serum insulin-like growth factor I regulates brain amyloid-beta levels. Nat. Med. 8, 1390-7. doi:10.1038/nm793

Cereda, E., Barichella, M., Cassani, E., Caccialanza, R., Pezzoli, G., 2012. Clinical features of Parkinson disease when onset of diabetes came first: A case-control study. Neurology 78, 1507-11. doi:10.1212/WNL.0b013e3182553cc9

Chen, S., An, F.-M., Yin, L., Liu, A.-R., Yin, D.-K., Yao, W.-B., Gao, X.-D., 2014. Glucagon-like peptide-1 protects hippocampal neurons against advanced glycation end product-induced tau hyperphosphorylation. Neuroscience 256, 137-46. doi:10.1016/j.neuroscience.2013.10.038

Chen, S., Liu, A., An, F., Yao, W., Gao, X., 2012. Amelioration of neurodegenerative changes in cellular and rat models of diabetes-related Alzheimer's disease by exendin-4. Age (Dordr). 
34, 1211-24. doi:10.1007/s11357-011-9303-8

Chen, Y., Zhang, Y., Li, L., Hölscher, C., 2015. Neuroprotective effects of geniposide in the MPTP mouse model of Parkinson's disease. Eur. J. Pharmacol. doi:10.1016/j.ejphar.2015.09.029

Cheng, Z., Tseng, Y., White, M.F., 2010. Insulin signaling meets mitochondria in metabolism. Trends Endocrinol. Metab. 21, 589-98. doi:10.1016/j.tem.2010.06.005

Cherry, J.D., Olschowka, J.A., O’Banion, M.K., 2014. Neuroinflammation and M2 microglia: the good, the bad, and the inflamed. J. Neuroinflammation 11, 98. doi:10.1186/1742-2094-1198

Chiu, S.-L., Chen, C.-M., Cline, H.T., 2008. Insulin receptor signaling regulates synapse number, dendritic plasticity, and circuit function in vivo. Neuron 58, 708-19. doi:10.1016/j.neuron.2008.04.014

Choi, J.-Y., Jang, E.-H., Park, C.-S., Kang, J.-H., 2005. Enhanced susceptibility to 1-methyl-4-phenyl1,2,3,6-tetrahydropyridine neurotoxicity in high-fat diet-induced obesity. Free Radic. Biol. Med. 38, 806-16. doi:10.1016/j.freeradbiomed.2004.12.008

Christensen, M., Sparre-Ulrich, A.H., Hartmann, B., Grevstad, U., Rosenkilde, M.M., Holst, J.J., Vilsbøll, T., Knop, F.K., 2015. Transfer of liraglutide from blood to cerebrospinal fluid is minimal in patients with type 2 diabetes. Int. J. Obes. 39, 1651-1654. doi:10.1038/ijo.2015.136

Copps, K.D., Hancer, N.J., Opare-Ado, L., Qiu, W., Walsh, C., White, M.F., 2010. Irs1 Serine 307 Promotes Insulin Sensitivity in Mice. Cell Metab. 11, 84-92. doi:10.1016/j.cmet.2009.11.003 De Pablo-Fernández, E., Breen, D.P., Bouloux, P.M., Barker, R.A., Foltynie, T., Warner, T.T., 2016. Neuroendocrine abnormalities in Parkinson's disease. J. Neurol. Neurosurg. Psychiatry jnnp-2016-314601. doi:10.1136/jnnp-2016-314601

De Pablo-Fernandez, E., Sierra-Hidalgo, F., Benito-León, J., Bermejo-Pareja, F., 2017. Association between Parkinson's disease and diabetes: Data from NEDICES study. Acta Neurol. Scand. doi:10.1111/ane.12793

Devaskar, S.U., Giddings, S.J., Rajakumar, P.A., Carnaghi, L.R., Menon, R.K., Zahm, D.S., 1994. Insulin gene expression and insulin synthesis in mammalian neuronal cells. J. Biol. Chem. 
$269,8445-54$.

Diehl, T., Mullins, R., Kapogiannis, D., 2017. Insulin resistance in Alzheimer's disease. Transl. Res. 183, 26-40. doi:10.1016/j.trsl.2016.12.005

Drucker, D.J., Philippe, J., Mojsov, S., Chick, W.L., Habener, J.F., 1987. Glucagon-like peptide I stimulates insulin gene expression and increases cyclic AMP levels in a rat islet cell line. Proc. Natl. Acad. Sci. U. S. A. 84, 3434-8.

Drucker, D.J., Sherman, S.I., Gorelick, F.S., Bergenstal, R.M., Sherwin, R.S., Buse, J.B., 2010. Incretinbased therapies for the treatment of type 2 diabetes: evaluation of the risks and benefits. Diabetes Care 33, 428-33. doi:10.2337/dc09-1499

Duka, T., Duka, V., Joyce, J.N., Sidhu, A., 2009. Alpha-Synuclein contributes to GSK-3beta-catalyzed Tau phosphorylation in Parkinson's disease models. FASEB J. 23, 2820-30. doi:10.1096/fj.08-120410

Fan, R., Li, X., Gu, X., Chan, J.C.N., Xu, G., 2010. Exendin-4 protects pancreatic beta cells from human islet amyloid polypeptide-induced cell damage: potential involvement of AKT and mitochondria biogenesis 815-824.

Foltynie, T., Aviles-Olmos, I., 2014. Exenatide as a potential treatment for patients with Parkinson's disease: First steps into the clinic. Alzheimers. Dement. 10, S38-S46. doi:10.1016/j.jalz.2013.12.005

Gallegos, S., Pacheco, C., Peters, C., Opazo, C.M., Aguayo, L.G., 2015. Features of alpha-synuclein that could explain the progression and irreversibility of Parkinson's disease. Front. Neurosci. 9, 59. doi:10.3389/fnins.2015.00059

Gao, S., Duan, C., Gao, G., Wang, X., Yang, H., 2015. Alpha-synuclein overexpression negatively regulates insulin receptor substrate 1 by activating mTORC1/S6K1 signaling. Int. J. Biochem. Cell Biol. 64, 25-33. doi:10.1016/j.biocel.2015.03.006

Giuntini, M., Baldacci, F., Del Prete, E., Bonuccelli, U., Ceravolo, R., 2014. Diabetes is associated with postural and cognitive domains in Parkinson's disease. Results from a single-center study. Parkinsonism Relat. Disord. 20, 671-2. doi:10.1016/j.parkreldis.2014.02.016

Goldin M, S.M., 2003. Protein kinase C and ERK involvement in dendritic spine plasticity in 
cultured rodent hippocampal neurons [WWW Document]. Eur J Neurosci. URL

http://www.ncbi.nlm.nih.gov/pubmed/?term=Goldin\%2CM.\%2C+Segal\%2CM.\%2C+2003.+ Protein+kinase+C+and+ERK+involvement+in+dendritic+spine+plas-+ticity (accessed 8.27.15).

Greene, L.A., Levy, O., Malagelada, C., 2011. Akt as a victim, villain and potential hero in Parkinson's disease pathophysiology and treatment. Cell. Mol. Neurobiol. 31, 969-78. doi:10.1007/s10571-011-9671-8

Hamilton, A., Patterson, S., Porter, D., Gault, V.A., Holscher, C., 2011. Novel GLP-1 mimetics developed to treat type 2 diabetes promote progenitor cell proliferation in the brain. J. Neurosci. Res. 89, 481-9. doi:10.1002/jnr.22565

Harkavyi, A., Abuirmeileh, A., Lever, R., Kingsbury, A.E., Biggs, C.S., Whitton, P.S., 2008. Glucagonlike peptide 1 receptor stimulation reverses key deficits in distinct rodent models of Parkinson's disease. J. Neuroinflammation 5, 19. doi:10.1186/1742-2094-5-19

Havrankova, J., Roth, J., Brownstein, M., 1978. Insulin receptors are widely distributed in the central nervous system of the rat. Nature 272, 827-9.

Heppner, K.M., Kirigiti, M., Secher, A., Paulsen, S.J., Buckingham, R., Pyke, C., Knudsen, L.B., Vrang, N., Grove, K.L., 2015. Expression and distribution of glucagon-like peptide-1 receptor mRNA, protein and binding in the male nonhuman primate (Macaca mulatta) brain. Endocrinology 156, 255-67. doi:10.1210/en.2014-1675

Hernandez-Baltazar, D., Mendoza-Garrido, M.E., Martinez-Fong, D., 2013. Activation of GSK-3 $\beta$ and caspase-3 occurs in Nigral dopamine neurons during the development of apoptosis activated by a striatal injection of 6-hydroxydopamine. PLoS One 8, e70951. doi:10.1371/journal.pone.0070951

Herschkovitz, A., Liu, Y.-F., Ilan, E., Ronen, D., Boura-Halfon, S., Zick, Y., 2007. Common Inhibitory Serine Sites Phosphorylated by IRS-1 Kinases, Triggered by Insulin and Inducers of Insulin Resistance. J. Biol. Chem. 282, 18018-18027. doi:10.1074/jbc.M610949200

Hill, J.M., Lesniak, M.A., Pert, C.B., Roth, J., 1986. Autoradiographic localization of insulin receptors in rat brain: prominence in olfactory and limbic areas. Neuroscience 17, 1127-38. 
Hu, G., Jousilahti, P., Bidel, S., Antikainen, R., Tuomilehto, J., 2007. Type 2 diabetes and the risk of Parkinson's disease. Diabetes Care 30, 842-7. doi:10.2337/dc06-2011

Hunter, K., Hölscher, C., 2012. Drugs developed to treat diabetes, liraglutide and lixisenatide, cross the blood brain barrier and enhance neurogenesis. BMC Neurosci. 13, 33. doi:10.1186/1471-2202-13-33

Ibáñez, P., Bonnet, A.-M., Débarges, B., Lohmann, E., Tison, F., Agid, Y., Dürr, A., Brice, A., Pollak, P., 2004. Causal relation between $\alpha$-synuclein locus duplication as a cause of familial Parkinson's disease. Lancet 364, 1169-1171. doi:10.1016/S0140-6736(04)17104-3

Irwin, D.J., Lee, V.M.-Y., Trojanowski, J.Q., 2013. Parkinson's disease dementia: convergence of $\alpha$ synuclein, tau and amyloid- $\beta$ pathologies. Nat. Rev. Neurosci. 14, 626-36. doi:10.1038/nrn3549

Jha, S.K., Jha, N.K., Kar, R., Ambasta, R.K., Kumar, P., 2015. p38 MAPK and PI3K/AKT Signalling Cascades inParkinson's Disease. Int. J. Mol. Cell. Med. 4, 67-86.

Jones, K.T., Woods, C., Zhen, J., Antonio, T., Carr, K.D., Reith, M.E.A., 2017. Effects of diet and insulin on dopamine transporter activity and expression in rat caudate-putamen, nucleus accumbens, and midbrain. J. Neurochem. 140, 728-740. doi:10.1111/jnc.13930

Kappe, C., Tracy, L.M., Patrone, C., Iverfeldt, K., Sjöholm, Å., 2012. GLP-1 secretion by microglial cells and decreased CNS expression in obesity. J. Neuroinflammation 9, 276. doi:10.1186/1742-2094-9-276

Kastin, A.J., Akerstrom, V., 2003. Entry of exendin-4 into brain is rapid but may be limited at high doses. Int. J. Obes. Relat. Metab. Disord. 27, 313-8. doi:10.1038/sj.ijo.0802206

Khasnavis, S., Jana, A., Roy, A., Mazumder, M., Bhushan, B., Wood, T., Ghosh, S., Watson, R., Pahan, K., 2012. Suppression of nuclear factor- $\kappa \mathrm{B}$ activation and inflammation in microglia by physically modified saline. J. Biol. Chem. 287, 29529-42. doi:10.1074/jbc.M111.338012

Kim, K.-S., Park, D.H., Wessel, T.C., Song, B., Wagner, J.A., Joh, T.H., 1993. A dual role for the cAMPdependent protein kinase in tyrosine hydroxylase gene expression. Neurobiology 90, 34713475.

Kim, S., Moon, M., Park, S., 2009. Exendin-4 protects dopaminergic neurons by inhibition of 
microglial activation and matrix metalloproteinase-3 expression in an animal model of Parkinson's disease. J. Endocrinol. 202, 431-9. doi:10.1677/JOE-09-0132

Kim, S.R., Ries, V., Cheng, H.-C., Kareva, T., Oo, T.F., Yu, W.H., Duff, K., Kholodilov, N., Burke, R.E., 2011. Age and $\alpha$-synuclein expression interact to reveal a dependence of dopaminergic axons on endogenous Akt/PKB signaling. Neurobiol. Dis. 44, 215-22. doi:10.1016/j.nbd.2011.07.003

Kleinridders, A., Cai, W., Cappellucci, L., Ghazarian, A., Collins, W.R., Vienberg, S.G., Pothos, E.N., Kahn, C.R., 2015. Insulin resistance in brain alters dopamine turnover and causes behavioral disorders. Proc. Natl. Acad. Sci. U. S. A. doi:10.1073/pnas.1500877112

Kuwabara, T., Kagalwala, M.N., Onuma, Y., Ito, Y., Warashina, M., Terashima, K., Sanosaka, T., Nakashima, K., Gage, F.H., Asashima, M., 2011. Insulin biosynthesis in neuronal progenitors derived from adult hippocampus and the olfactory bulb. EMBO Mol. Med. 3, 742-54. doi:10.1002/emmm.201100177

Lee, C.-C., Huang, C.-C., Wu, M.-Y., Hsu, K.-S., 2005. Insulin stimulates postsynaptic density-95 protein translation via the phosphoinositide 3-kinase-Akt-mammalian target of rapamycin signaling pathway. J. Biol. Chem. 280, 18543-50. doi:10.1074/jbc.M414112200

Lee, Y.H., Giraud, J., Davis, R.J., White, M.F., 2003. c-Jun N-terminal Kinase (JNK) Mediates Feedback Inhibition of the Insulin Signaling Cascade. J. Biol. Chem. 278, 2896-2902. doi:10.1074/jbc.M208359200

Li, Y., Li, L., Hölscher, C., 2016. Incretin-based therapy for type 2 diabetes mellitus is promising for treating neurodegenerative diseases. Rev. Neurosci. 0, 1-23. doi:10.1515/revneuro2016-0018

Li, Y., Perry, T., Kindy, M.S., Harvey, B.K., Tweedie, D., Holloway, H.W., Powers, K., Shen, H., Egan, J.M., Sambamurti, K., Brossi, A., Lahiri, D.K., Mattson, M.P., Hoffer, B.J., Wang, Y., Greig, N.H., 2009. GLP-1 receptor stimulation preserves primary cortical and dopaminergic neurons in cellular and rodent models of stroke and Parkinsonism. PNAS 106, 1285-1290.

Li, Y., Tweedie, D., Mattson, M.P., Holloway, H.W., Greig, N.H., 2010. Enhancing the GLP-1 receptor signaling pathway leads to proliferation and neuroprotection in human neuroblastoma cells. 
J. Neurochem. 113, 1621-31. doi:10.1111/j.1471-4159.2010.06731.x

Li, Z., Zhou, Z., Huang, G., Hu, F., Xiang, Y., He, L., 2013. Exendin-4 protects mitochondria from reactive oxygen species induced apoptosis in pancreatic Beta cells. PLoS One 8, e76172. doi:10.1371/journal.pone.0076172

Liu, W., Jalewa, J., Sharma, M., Li, G., Li, L., Hölscher, C., 2015. Neuroprotective effects of lixisenatide and liraglutide in the 1-methyl-4-phenyl-1,2,3,6-tetrahydropyridine mouse model of Parkinson's disease. Neuroscience 303, 42-50.

doi:10.1016/j.neuroscience.2015.06.054

Lovshin, J.A., Drucker, D.J., 2009. Incretin-based therapies for type 2 diabetes mellitus. Nat. Rev. Endocrinol. 5, 262-9. doi:10.1038/nrendo.2009.48

Ma, D.-L., Chen, F.-Q., Xu, W.-J., Yue, W.-Z., Yuan, G., Yang, Y., 2015. Early Intervention with Glucagon-like Peptide 1 Analog Liraglutide Prevents Tau Hyperphosphorylation in Diabetic db/db Mice. J. Neurochem. doi:10.1111/jnc.13248

Madsbad, S., 2016. Review of head-to-head comparisons of glucagon-like peptide-1 receptor agonists. Diabetes. Obes. Metab. 18, 317-32. doi:10.1111/dom.12596

Mainardi, M., Fusco, S., Grassi, C.,. Modulation of Hippocampal Neural Plasticity by GlucoseRelated Signaling. Neural Plast. 2015, 657928. doi:10.1155/2015/657928

Manigault, K., Thurston, M.M., 2016. Liraglutide: A Glucagon-Like Peptide-1 Agonist for Chronic Weight Management. Consult. Pharm. 31, 685-697. doi:10.4140/TCP.n.2016.685

Mann, K. V, Raskin, P., 2014. Exenatide extended-release: a once weekly treatment for patients with type 2 diabetes. Diabetes. Metab. Syndr. Obes. 7, 229-39. doi:10.2147/DMSO.S35331

Marciniak, E., Leboucher, A., Caron, E., Ahmed, T., Tailleux, A., Dumont, J., Issad, T., Gerhardt, E., Pagesy, P., Vileno, M., Bournonville, C., Hamdane, M., Bantubungi, K., Lancel, S., Demeyer, D., Eddarkaoui, S., Vallez, E., Vieau, D., Humez, S., Faivre, E., Grenier-Boley, B., Outeiro, T.F., Staels, B., Amouyel, P., Balschun, D., Buee, L., Blum, D., 2017. Tau deletion promotes brain insulin resistance. J. Exp. Med. 214.

Martin, F.L., Williamson, S.J.M., Paleologou, K.E., Allsop, D., El-Agnaf, O.M.A., 2004. Alphasynuclein and the pathogenesis of Parkinson's disease. Protein Pept. Lett. 11, 229-37. 
Moloney, A.M., Griffin, R.J., Timmons, S., O’Connor, R., Ravid, R., O’Neill, C., 2010. Defects in IGF-1 receptor, insulin receptor and IRS-1/2 in Alzheimer's disease indicate possible resistance to IGF-1 and insulin signalling. Neurobiol. Aging 31, 224-43.

doi:10.1016/j.neurobiolaging.2008.04.002

Mora, P.F., Johnson, E.L., 2017. CARDIOVASCULAR OUTCOME TRIALS OF THE INCRETIN-BASED THERAPIES: WHAT DO WE KNOW SO FAR? Endocr. Pract. 23, 89-99. doi:10.4158/EP161481.RA

Morris, J.K., Bomhoff, G.L., Gorres, B.K., Davis, V.A., Kim, J., Lee, P.-P., Brooks, W.M., Gerhardt, G.A., Geiger, P.C., Stanford, J.A., 2011. Insulin resistance impairs nigrostriatal dopamine function. Exp. Neurol. 231, 171-180. doi:10.1016/j.expneurol.2011.06.005

Morris, J.K., Bomhoff, G.L., Stanford, J.A., Geiger, P.C., 2010. Neurodegeneration in an animal model of Parkinson's disease is exacerbated by a high-fat diet. AJP Regul. Integr. Comp. Physiol. 299, R1082-R1090. doi:10.1152/ajpregu.00449.2010

Morris, J.K., Zhang, H., Gupte, A.A., Bomhoff, G.L., Stanford, J.A., Geiger, P.C., 2008. Measures of striatal insulin resistance in a 6-hydroxydopamine model of Parkinson's disease. Brain Res. 1240, 185-95. doi:10.1016/j.brainres.2008.08.089

Moussaud, S., Jones, D.R., Moussaud-Lamodière, E.L., Delenclos, M., Ross, O.A., McLean, P.J., 2014. Alpha-synuclein and tau: teammates in neurodegeneration? Mol. Neurodegener. 9, 43. doi:10.1186/1750-1326-9-43

Müssig, K., Staiger, H., Fiedler, H., Moeschel, K., Beck, A., Kellerer, M., Häring, H.-U., 2005. Shp2 Is Required for Protein Kinase C-dependent Phosphorylation of Serine 307 in Insulin Receptor Substrate-1. J. Biol. Chem. 280, 32693-32699. doi:10.1074/jbc.M506549200

Nagao, M., Hayashi, H., 2009. Glycogen synthase kinase-3beta is associated with Parkinson's disease. Neurosci. Lett. 449, 103-107. doi:10.1016/j.neulet.2008.10.104

Nassar, N.N., Al-Shorbagy, M.Y., Arab, H.H., Abdallah, D.M., 2015. Saxagliptin: a novel antiparkinsonian approach. Neuropharmacology 89, 308-17. doi:10.1016/j.neuropharm.2014.10.007

Palacios, N., Gao, X., McCullough, M.L., Jacobs, E.J., Patel, A. V, Mayo, T., Schwarzschild, M.A., 
Ascherio, A., 2011. Obesity, diabetes, and risk of Parkinson's disease. Mov. Disord. 26, 22539. doi:10.1002/mds.23855

Park, M.H., Kim, D.H., Lee, E.K., Kim, N.D., Im, D.S., Lee, J., Yu, B.P., Chung, H.Y., 2014. Age-related inflammation and insulin resistance: a review of their intricate interdependency. Arch. Pharm. Res. 37, 1507-14. doi:10.1007/s12272-014-0474-6

Parkes, D.G., Mace, K.F., Trautmann, M.E., 2013. Discovery and development of exenatide: the first antidiabetic agent to leverage the multiple benefits of the incretin hormone, GLP-1. Expert Opin. Drug Discov. 8, 219-44. doi:10.1517/17460441.2013.741580

Perruolo, G., Viggiano, D., Fiory, F., Cassese, A., Nigro, C., Liotti, A., Miele, C., Beguinot, F., Formisano, P., 2016. Parkinson-like phenotype in insulin-resistant PED/PEA-15 transgenic mice. Sci. Rep. 6, 29967. doi:10.1038/srep29967

Perry, T., Lahiri, D.K., Chen, D., Zhou, J., Shaw, K.T.Y., Egan, J.M., Greig, N.H., 2002. A novel neurotrophic property of glucagon-like peptide 1: a promoter of nerve growth factormediated differentiation in PC12 cells. J. Pharmacol. Exp. Ther. 300, 958-66.

Prasad-Reddy, L., Isaacs, D., 2015. A clinical review of GLP-1 receptor agonists: efficacy and safety in diabetes and beyond. Drugs Context 4, 212283. doi:10.7573/dic.212283

Rannikko, E.H., Weber, S.S., Kahle, P.J., 2015. Exogenous $\alpha$-synuclein induces toll-like receptor 4 dependent inflammatory responses in astrocytes. BMC Neurosci. 16, 57. doi:10.1186/s12868-015-0192-0

Reagan, L.P., 2012. Diabetes as a chronic metabolic stressor: causes, consequences and clinical complications. Exp. Neurol. 233, 68-78. doi:10.1016/j.expneurol.2011.02.004

Reddy, I.A., Pino, J.A., Weikop, P., Osses, N., Sørensen, G., Bering, T., Valle, C., Bluett, R.J., Erreger, K., Wortwein, G., Reyes, J.G., Graham, D., Stanwood, G.D., Hackett, T.A., Patel, S., Fink-Jensen, A., Torres, G.E., Galli, A., 2016. Glucagon-like peptide 1 receptor activation regulates cocaine actions and dopamine homeostasis in the lateral septum by decreasing arachidonic acid levels. Transl. Psychiatry 6, e809. doi:10.1038/tp.2016.86

Reiner, D.J., Mietlicki-Baase, E.G., McGrath, L.E., Zimmer, D.J., Bence, K.K., Sousa, G.L., Konanur, V.R., Krawczyk, J., Burk, D.H., Kanoski, S.E., Hermann, G.E., Rogers, R.C., Hayes, M.R., 2016. 
Astrocytes Regulate GLP-1 Receptor-Mediated Effects on Energy Balance. J. Neurosci. 36, 3531-40. doi:10.1523/JNEUROSCI.3579-15.2016

Schapira, A.H. V, 2008. Mitochondria in the aetiology and pathogenesis of Parkinson's disease. Lancet Neurol. 7, 97-109. doi:10.1016/S1474-4422(07)70327-7

Schernhammer, E., Hansen, J., Rugbjerg, K., Wermuth, L., Ritz, B., 2011. Diabetes and the risk of developing Parkinson's disease in Denmark. Diabetes Care 34, 1102-8. doi:10.2337/dc101333

Seufert, J., Gallwitz, B., 2014. The extra-pancreatic effects of GLP-1 receptor agonists: a focus on the cardiovascular, gastrointestinal and central nervous systems. Diabetes. Obes. Metab. 16, 673-88. doi:10.1111/dom.12251

Sharma, S.K., Chorell, E., Steneberg, P., Vernersson-Lindahl, E., Edlund, H., Wittung-Stafshede, P., 2015. Insulin-degrading enzyme prevents $\alpha$-synuclein fibril formation in a nonproteolytical manner. Sci. Rep. 5, 12531. doi:10.1038/srep12531

Sharma, S.K., Chorell, E., Wittung-Stafshede, P., 2015. Insulin-degrading enzyme is activated by the C-terminus of $\alpha$-synuclein. Biochem. Biophys. Res. Commun. 466, 192-195. doi:10.1016/j.bbrc.2015.09.002

Shiraishi, D., Fujiwara, Y., Komohara, Y., Mizuta, H., Takeya, M., 2012. Glucagon-like peptide-1 (GLP-1) induces M2 polarization of human macrophages via STAT3 activation. Biochem. Biophys. Res. Commun. 425, 304-8. doi:10.1016/j.bbrc.2012.07.086

Singleton, A.B., Farrer, M., Johnson, J., Singleton, A., Hague, S., Kachergus, J., Hulihan, M., Peuralinna, T., Dutra, A., Nussbaum, R., Lincoln, S., Crawley, A., Hanson, M., Maraganore, D., Adler, C., Cookson, M.R., Muenter, M., Baptista, M., Miller, D., Blancato, J., Hardy, J., GwinnHardy, K., 2003. Alpha Synuclein Locus Triplication Causes Parkinson's Disease. Science (80. ). 302, 841-841. doi:10.1126/science.1090278

Spielman, L.J., Gibson, D.L., Klegeris, A., 2017. Incretin hormones regulate microglia oxidative stress, survival and expression of trophic factors. Eur. J. Cell Biol. 96, 240-253. doi:10.1016/j.ejcb.2017.03.004

Stouffer, M.A., Woods, C.A., Patel, J.C., Lee, C.R., Witkovsky, P., Bao, L., Machold, R.P., Jones, K.T., de 
Vaca, S.C., Reith, M.E.A., Carr, K.D., Rice, M.E., 2015. Insulin enhances striatal dopamine release by activating cholinergic interneurons and thereby signals reward. Nat. Commun. 6 , 8543. doi:10.1038/ncomms9543

Sun, J., Xia, W., Cai, R., Wang, P., Huang, R., Sun, H., Tian, S., Dong, X., Wang, S., 2016. Serum Insulin Degrading Enzyme Level and Other Factors in Type 2 Diabetic Patients with Mild Cognitive Impairment. Curr. Alzheimer Res. 13, 1337-1345.

Sun, Y., Chang, Y.-H., Chen, H.-F., Su, Y.-H., Su, H.-F., Li, C.-Y., 2012. Risk of Parkinson disease onset in patients with diabetes: a 9-year population-based cohort study with age and sex stratifications. Diabetes Care 35, 1047-9. doi:10.2337/dc11-1511

Svenningsson, P., Wirdefeldt, K., Yin, L., Fang, F., Markaki, I., Efendic, S., Ludvigsson, J.F., 2016. Reduced incidence of Parkinson's disease after dipeptidyl peptidase-4 inhibitors-A nationwide case-control study. Mov. Disord. doi:10.1002/mds.26734

Talbot, K., Wang, H.-Y., Kazi, H., Han, L.-Y., Bakshi, K.P., Stucky, A., Fuino, R.L., Kawaguchi, K.R., Samoyedny, A.J., Wilson, R.S., Arvanitakis, Z., Schneider, J.A., Wolf, B.A., Bennett, D.A., Trojanowski, J.Q., Arnold, S.E., 2012. Demonstrated brain insulin resistance in Alzheimer's disease patients is associated with IGF-1 resistance, IRS-1 dysregulation, and cognitive decline. J. Clin. Invest. 122, 1316-38. doi:10.1172/JCI59903

Teramoto, S., Miyamoto, N., Yatomi, K., Tanaka, Y., Oishi, H., Arai, H., Hattori, N., Urabe, T., 2011. Exendin-4, a glucagon-like peptide-1 receptor agonist, provides neuroprotection in mice transient focal cerebral ischemia. J. Cereb. Blood Flow Metab. 31, 1696-705. doi:10.1038/jcbfm.2011.51

Tews, D., Lehr, S., Hartwig, S., Osmers, A., Paslack, W., Eckel, J., 2009. Anti-apoptotic action of exendin-4 in INS-1 beta cells: comparative protein pattern analysis of isolated mitochondria. Horm. Metab. Res. 41, 294-301. doi:10.1055/s-0028-1105911

Tokutake, T., Kasuga, K., Yajima, R., Sekine, Y., Tezuka, T., Nishizawa, M., Ikeuchi, T., 2012. Hyperphosphorylation of Tau induced by naturally secreted amyloid- $\beta$ at nanomolar concentrations is modulated by insulin-dependent Akt-GSK3 $\beta$ signaling pathway. J. Biol. Chem. 287, 35222-33. doi:10.1074/jbc.M112.348300 
Trapp, S., Cork, S.C., Abbas, T., Faivre, E., Holscher, C., Abbott, S., Stornetta, R., Socolovsky, C.,

West, G., Guyenet, P., Abdelsalam, R., Safar, M., Alhadeff, A., Baird, J., Swick, J., Hayes, M., Grill, H., Alhadeff, A., Rupprecht, L., Hayes, M., Asarian, L., Baraboi, E., Smith, P., Ferguson, A., Richard, D., Barrera, J., Jones, K., Herman, J., D’Alessio, D., Woods, S., Seeley, R., Beiroa, D., Imbernon, M., Gallego, R., Senra, A., Herranz, D., Villarroya, F., Serrano, M., Ferno, J., Salvador, J., Escalada, J., Dieguez, C., Lopez, M., Fruhbeck, G., Nogueiras, R., Cabou, C., Campistron, G., Marsollier, N., Leloup, C., Cruciani-Guglielmacci, C., Penicaud, L., Drucker, D., Magnan, C., Burcelin, R., Felice, F. De, Dickson, S., Shirazi, R., Hansson, C., Bergquist, F., Nissbrandt, H., Skibicka, K., Dossat, A., Diaz, R., Gallo, L., Panagos, A., Kay, K., Williams, D., Dossat, A., Lilly, N., Kay, K., Williams, D., Drucker, D., During, M., Cao, L., Zuzga, D., Francis, J., Fitzsimons, H., Jiao, X., Bland, R., Klugmann, M., Banks, W., Drucker, D., Haile, C., Egecioglu, E., Engel, J., Jerlhag, E., Egecioglu, E., Steensland, P., Fredriksson, I., Feltmann, K., Engel, J., Jerlhag, E., Erreger, K., Davis, A., Poe, A., Greig, N., Stanwood, G., Galli, A., Flint, A., Raben, A., Astrup, A., Holst, J., Gault, V., Holscher, C., Gilman, C., Perry, T., Furukawa, K., Grieg, N., Egan, J., Mattson, M., Goldstone, A., Mercer, J., Gunn, I., Moar, K., Edwards, C., Rossi, M., Howard, J., Rasheed, S., Turton, M., Small, C., Heath, M., O’Shea, D., Steere, J., Meeran, K., Ghatei, M., Hoggard, N., Bloom, S., Goldstone, A., Morgan, I., Mercer, J., Morgan, D., Moar, K., Ghatei, M., Bloom, S., Graham, D., Erreger, K., Galli, A., Stanwood, G., Grill, H., Carmody, J., Sadacca, L.A., Williams, D., Kaplan, J., Gutzwiller, J., Goke, B., Drewe, J., Hildebrand, P., Ketterer, S., Handschin, D., Winterhalder, R., Conen, D., Beglinger, C., Halford, J., Boyland, E., Blundell, J., Kirkham, T., Harrold, J., Hansen, H., Fabricius, K., Barkholt, P., Niehoff, M., Morley, J., Jelsing, J., Pyke, C., Knudsen, L.B., Farr, S., Vrang, N., Hayes, M., Bradley, L., Grill, H., Hayes, M., Kanoski, S., Jonghe, B. De, Leichner, T., Alhadeff, A., Fortin, S., Arnold, M., Langhans, W., Grill, H., Hayes, M., Skibicka, K., Grill, H., Heppner, K., Kirigiti, M., Secher, A., Paulsen, S., Buckingham, R., Pyke, C., Knudsen, L., Vrang, N., Grove, K., Hisadome, K., Reimann, F., Gribble, F., Trapp, S., Hisadome, K., Reimann, F., Gribble, F., Trapp, S., Holmes, G., Browning, K., Tong, M., QuallsCreekmore, E., Travagli, R., Hsu, T., Hahn, J., Konanur, V., Lam, A., Kanoski, S., Huo, L., Gamber, K., Grill, H., Bjorbaek, C., Jin, S., Han, V., Simmons, J., Towle, A., Lauder, J., Lund, P., 
Jun, L., Showalter, A., Ali, N., Dai, F., Ma, W., Coskun, T., Ficorilli, J., Wheeler, M., Michael, M., Sloop, K., Kanoski, S., Rupprecht, L., Fortin, S., Jonghe, B. De, Hayes, M., Kastin, A., Akerstrom, V., Pan, W., Kinzig, K., D’Alessio, D., Seeley, R., Knauf, C., Cani, P., Ait-Belgnaoui, A., Benani, A., Dray, C., Cabou, C., Colom, A., Uldry, M., Rastrelli, S., Sabatier, E., Godet, N., Waget, A., Penicaud, L., Valet, P., Burcelin, R., Knauf, C., Cani, P., Perrin, C., Iglesias, M., Maury, J., Bernard, E., Benhamed, F., Gremeaux, T., Drucker, D., Kahn, C., Girard, J., Tanti, J., Delzenne, N., Postic, C., Burcelin, R., Kopf, B., Langhans, W., Geary, N., Asarian, L., Korol, S., Jin, Z., Babateen, O., Birnir, B., Kreisler, A., Davis, E., Rinaman, L., Lam, D., Garfield, A., Marston, O., Shaw, J., Heisler, L., Langhans, W., Larsen, P., Tang-Christensen, M., Holst, J., Orskov, C., Lennox, R., Flatt, P., Gault, V., Liu, W., Jalewa, J., Sharma, M., Li, G., Li, L., Holscher, C., Llewellyn-Smith, I., Gnanamanickam, G., Reimann, F., Gribble, F., Trapp, S., Llewellyn-Smith, I., Marina, N., Manton, R., Reimann, F., Gribble, F., Trapp, S., Llewellyn-Smith, I., Reimann, F., Gribble, F., Trapp, S., Lockie, S., Andrews, Z., Lockie, S., Heppner, K., Chaudhary, N., Chabenne, J., Morgan, D., Veyrat-Durebex, C., Ananthakrishnan, G., Rohner-Jeanrenaud, F., Drucker, D., DiMarchi, R., Rahmouni, K., Oldfield, B., Tschop, M., Perez-Tilve, D., Maniscalco, J., Rinaman, L., Manning, S., Pucci, A., Batterham, R., Marina, N., Abdala, A., Trapp, S., Li, A., Nattie, E., Hewinson, J., Smith, J., Paton, J., Gourine, A., McMahon, L., Wellman, P., Merchenthaler, I., Lane, M., Shughrue, P., Mietlicki-Baase, E., Ortinski, P., Reiner, D., Sinon, C., McCutcheon, J., Pierce, R., Roitman, M., Hayes, M., Mietlicki-Baase, E., Ortinski, P., Rupprecht, L., Olivos, D., Alhadeff, A., Pierce, R., Hayes, M., Morris, J., Pow, D., Morris, J., Vidoni, E., Honea, R., Burns, J., neuroimaging, I.A. disease, Morrison, S., Nakamura, K., Madden, C., Oka, J., Goto, N., Kameyama, T., Orskov, C., Poulsen, S., Moller, M., Holst, J., Palouzier-Paulignan, B., Lacroix, M., Aime, P., Baly, C., Caillol, M., Congar, P., Julliard, A., Tucker, K., Fadool, D., Parker, H., Adriaenssens, A., Rogers, G., Richards, P., Koepsell, H., Reimann, F., Gribble, F., Plamboeck, A., Veedfald, S., Deacon, C., Hartmann, B., Wettergren, A., Svendsen, L., Meisner, S., Hovendahl, C., Vilsboll, T., Knop, F., Holst, J., Punjabi, M., Arnold, M., Ruttimann, E., Graber, M., Geary, N., Pacheco-Lopez, G., Langhans, W., Richard, J., Anderberg, R., Goteson, A., Gribble, F., Reimann, F., Skibicka, K., Richard, J., Farkas, I., Anesten, F., Anderberg, R., Dickson, S., Gribble, F., 
Reimann, F., Jansson, J., Liposits, Z., Skibicka, K., Richards, P., Parker, H., Adriaenssens, A., Hodgson, J., Cork, S., Trapp, S., Gribble, F., Reimann, F., Rinaman, L., Fonseca, F.R. de, Navarro, M., Alvarez, E., Roncero, I., Chowen, J., Maestre, O., Gomez, R., Munoz, R., Eng, J., Blazquez, E., Ronveaux, C., Tome, D., Raybould, H., Ruttimann, E., Arnold, M., Hillebrand, J., Geary, N., Langhans, W., Sandoval, D., Bagnol, D., Woods, S., D’Alessio, D., Seeley, R., Sandoval, D., D’Alessio, D., Secher, A., Jelsing, J., Baquero, A., Hecksher-Sorensen, J., Cowley, M., Dalboge, L., Hansen, G., Grove, K., Pyke, C., Raun, K., Schaffer, L., Tang-Christensen, M., Verma, S., Witgen, B., Vrang, N., Knudsen, L.B., Shimizu, I., Hirota, M., Ohboshi, C., Shima, K., Shirazi, R., Dickson, S., Skibicka, K., Skibicka, K., Stern, J., Tang-Christensen, M., Larsen, P., Goke, R., Fink-Jensen, A., Jessop, D., Moller, M., Sheikh, S., Tauchi, M., Zhang, R., D’Alessio, D., Stern, J., Herman, J., Thiele, T., Dijk, G. Van, Campfield, L., Smith, F., Burn, P., Woods, S., Bernstein, I., Seeley, R., Turton, M., O’Shea, D., Gunn, I., Beak, S., Edwards, C., Meeran, K., Choi, S., Taylor, G., Heath, M., Lambert, P., Wilding, J., Smith, D., Ghatei, M., Herbert, J., Bloom, S., Pol, A. van den, Dijk, G. van, Thiele, T., Vrang, N., Grove, K., Vrang, N., Hansen, M., Larsen, P., TangChristensen, M., Vrang, N., Phifer, C., Corkern, M., Berthoud, H., Wan, S., Coleman, F., Travagli, R., Williams, D., Baskin, D., Schwartz, M., Williams, D., Baskin, D., Schwartz, M., Xu, W., Yang, Y., Yuan, G., Zhu, W., Ma, D., Hu, S., Yamamoto, H., Kishi, T., Lee, C., Choi, B., Fang, H., Hollenberg, A., Drucker, D., Elmquist, J., Yamamoto, H., Lee, C., Marcus, J., Williams, T., Overton, J., Lopez, M., Hollenberg, A., Baggio, L., Saper, C., Drucker, D., Elmquist, J., Yoshino, Y., Ishisaka, M., Tsujii, S., Shimazawa, M., Hara, H., Zhang, J., Ritter, R., Zhao, S., Kanoski, S., Yan, J., Grill, H., Hayes, M., Zheng, H., Cai, L., Rinaman, L., Zheng, H., Stornetta, R., Agassandian, K., Rinaman, L., 2015. PPG neurons of the lower brain stem and their role in brain GLP-1 receptor activation. Am. J. Physiol. Regul. Integr. Comp. Physiol. 309, R795-804. doi:10.1152/ajpregu.00333.2015

Tremblay, F., Brule, S., Hee Um, S., Li, Y., Masuda, K., Roden, M., Sun, X.J., Krebs, M., Polakiewicz, R.D., Thomas, G., Marette, A., 2007. Identification of IRS-1 Ser-1101 as a target of S6K1 in nutrient- and obesity-induced insulin resistance. Proc. Natl. Acad. Sci. 104, 14056-14061. doi:10.1073/pnas.0706517104 
Ventorp, F., Bay-Richter, C., Nagendra, A.S., Janelidze, S., Matsson, V.S., Lipton, J., Nordström, U., Westrin, Åsa, Brundin, P., Brundin, L., 2017. Exendin-4 Treatment Improves LPS-Induced Depressive-Like Behavior Without Affecting Pro-Inflammatory Cytokines. J. Parkinsons. Dis. 7, 263-273. doi:10.3233/JPD-171068

Wahlqvist, M.L., Lee, M.-S., Hsu, C.-C., Chuang, S.-Y., Lee, J.-T., Tsai, H.-N., 2012. Metformininclusive sulfonylurea therapy reduces the risk of Parkinson's disease occurring with Type 2 diabetes in a Taiwanese population cohort. Parkinsonism Relat. Disord. 18, 753-8. doi:10.1016/j.parkreldis.2012.03.010

Wang, L., Zhai, Y.-Q., Xu, L.-L., Qiao, C., Sun, X.-L., Ding, J.-H., Lu, M., Hu, G., 2014. Metabolic inflammation exacerbates dopaminergic neuronal degeneration in response to acute MPTP challenge in type 2 diabetes mice. Exp. Neurol. 251, 22-9.

doi:10.1016/j.expneurol.2013.11.001

Wang, M.-D., Huang, Y., Zhang, G.-P., Mao, L., Xia, Y.-P., Mei, Y.-W., Hu, B., 2012. Exendin-4 improved rat cortical neuron survival under oxygen/glucose deprivation through PKA pathway. Neuroscience 226, 388-96. doi:10.1016/j.neuroscience.2012.09.025

Wang, Q., Li, L., Xu, E., Wong, V., Rhodes, C., Brubaker, P.L., 2004. Glucagon-like peptide-1 regulates proliferation and apoptosis via activation of protein kinase B in pancreatic INS-1 beta cells. Diabetologia 47, 478-87. doi:10.1007/s00125-004-1327-5

Watson, G.S., Peskind, E.R., Asthana, S., Purganan, K., Wait, C., Chapman, D., Schwartz, M.W., Plymate, S., Craft, S., 2003. Insulin increases CSF Abeta42 levels in normal older adults. Neurology 60, 1899-903.

Wills, J., Jones, J., Haggerty, T., Duka, V., Joyce, J.N., Sidhu, A., 2010. Elevated tauopathy and alphasynuclein pathology in postmortem Parkinson's disease brains with and without dementia. Exp. Neurol. 225, 210-8. doi:10.1016/j.expneurol.2010.06.017

Xu, Q., Park, Y., Huang, X., Hollenbeck, A., Blair, A., Schatzkin, A., Chen, H., 2011. Diabetes and risk of Parkinson's disease. Diabetes Care 34, 910-5. doi:10.2337/dc10-1922

Xu, W., Yang, Y., Yuan, G., Zhu, W., Ma, D., Hu, S., 2015. Exendin-4, a glucagon-like peptide-1 receptor agonist, reduces Alzheimer disease-associated tau hyperphosphorylation in the 
hippocampus of rats with type 2 diabetes. J. Investig. Med. 63, 267-72.

doi:10.1097/JIM.0000000000000129

Yang, Y., Zhang, J., Ma, D., Zhang, M., Hu, S., Shao, S., Gong, C.-X., 2013. Subcutaneous

administration of liraglutide ameliorates Alzheimer-associated tau hyperphosphorylation in rats with type 2 diabetes. J. Alzheimers. Dis. 37, 637-48. doi:10.3233/JAD-130491

Yao, W.-D., Gainetdinov, R.R., Arbuckle, M.I., Sotnikova, T.D., Cyr, M., Beaulieu, J.-M., Torres, G.E., Grant, S.G.N., Caron, M.G., 2004. Identification of PSD-95 as a regulator of dopaminemediated synaptic and behavioral plasticity. Neuron 41, 625-38.

Yarchoan, M., Toledo, J.B., Lee, E.B., Arvanitakis, Z., Kazi, H., Han, L.-Y., Louneva, N., Lee, V.M.-Y., Kim, S.F., Trojanowski, J.Q., Arnold, S.E., 2014. Abnormal serine phosphorylation of insulin receptor substrate 1 is associated with tau pathology in Alzheimer's disease and tauopathies. Acta Neuropathol. 128, 679-689. doi:10.1007/s00401-014-1328-5

Zhan, Y., Sun, H., Chen, H., Zhang, H., Sun, J., Zhang, Z., Cai, D., 2012. Glucagon-like peptide-1 (GLP1) protects vascular endothelial cells against advanced glycation end products (AGEs)induced apoptosis. Med. Sci. Monit. 18, BR286-91.

Zhang, H., Meng, J., Li, X., Zhou, S., Qu, D., Wang, N., Jia, M., Ma, X., Luo, X., 2015. Pro-GLP-1, a Prodrug of GLP-1, is neuroprotective in cerebral ischemia. Eur. J. Pharm. Sci. 70, 82-91. doi:10.1016/j.ejps.2015.01.010

Zhang, Y., Xia, Z., Liu, J., Yin, F., 2015. Cell Signaling Mechanisms by which Geniposide Regulates Insulin- Degrading Enzyme Expression in Primary Cortical Neurons. CNS Neurol. Disord. Drug Targets 14, 370-7.

Zhao, W.-Q., Townsend, M., 2009. Insulin resistance and amyloidogenesis as common molecular foundation for type 2 diabetes and Alzheimer's disease. Biochim. Biophys. Acta 1792, 48296. doi:10.1016/j.bbadis.2008.10.014

Zhou, H., Li, D., Shi, C., Xin, T., Yang, J., Zhou, Y., Hu, S., Tian, F., Wang, J., Chen, Y., 2015. Effects of Exendin-4 on bone marrow mesenchymal stem cell proliferation, migration and apoptosis in vitro. Sci. Rep. 5, 12898. doi:10.1038/srep12898 